\title{
CHEMICAL AND MICROBIOLOGICAL PROPERTIES OF HUNGARIAN SANDY SOILS UNDER DIFFERENT MANAGEMENT PRACTICES
}

\author{
DEMETER, I. ${ }^{1 *}$ - MAKÁDI, M. ${ }^{1}-$ TOMÓCSIK, A. ${ }^{1}-$ ARANYOS, T. J. ${ }^{1}-$ MichÉLI, E. ${ }^{2}-$ POSTA, K. ${ }^{3}$ \\ ${ }^{1}$ Research Institute of Nyíregyháza, Institutes for Agricultural Research and Educational Farm \\ University of Debrecen \\ Westsik Vilmos Street, 4400 Nyíregyháza, Hungary \\ ${ }^{2}$ Department of Soil Science and Agricultural Chemistry, Szent István University \\ Páter Károly Street, 2100 Gödöllö, Hungary \\ ${ }^{3}$ Institute of Genetics, Microbiology and Biotechnology, Szent István University \\ Páter Károly Street, 2100 Gödöllö, Hungary \\ *Corresponding author \\ e-mail: ibolyad85@gmail.com \\ (Received $12^{\text {th }}$ Mar 2018; accepted 24 $4^{\text {th }}$ May 2018)
}

\begin{abstract}
The type and the management have strong effect on the composition and activity of microbial community and therefore on fertility of the soil. In this study ecological and conventional managements were compared in a sandy area of the Nyírség (North-Eastern) region, Hungary. Soil samples were collected twice from the upper and lower part of the sloping study sites, in autumn 2012 and in spring 2013, from the $0-30 \mathrm{~cm}$ and $30-60 \mathrm{~cm}$ depth intervals. Beside the main physical and chemical soil properties, the community structure (phospholipid fatty acid characterization) and activity (invertase and catalase enzymes) of microbes were investigated. The recycled plant residues can buffering the negative environmental/human effects, decreases the differences between the chemical and microbiological results of two elevation positions, and results favourable conditions to the soil microbes. Higher $\mathrm{pH}$, total and organic $\mathrm{C}$ content, total and nitrite-nitrate- $\mathrm{N}$ content, furthermore higher enzymatic activities were measured in the ecological than in conventional site. Our results showed that ecological management had positive effect on the quality and fertility of the sandy soils in the Nyírség region by improving the chemical soil parameters and increasing the community size and the activity of microbes. Most of the measured parameters were more favourable in the $0-30 \mathrm{~cm}$ than the lower sampled layer.

Keywords: sandy soils, ecological management, conventional management, soil microbiological properties
\end{abstract}

\section{Introduction}

The global human population is 7.5 billion and it is expected to reach 9.7 billion by 2050 (UN, 2015). Thus, applying the rules of sustainable management is essential to meet the growing demand for food. Organic production is a management system based on best environmental practices, a high level of biodiversity, the preservation of natural resources and the application of high animal welfare standards. In contrast, conventional management system focuses firstly on high crop yield, however the demand for healthy foods has been started to emerge.

In ecological management mineral fertilizers could be replaced with green manure, manure, recycled crop residues. In Hungary, the ecological management is carried out in accordance with the 834/2007 and 889/2008 EU Commission Regulations. Pesticides and mineral fertilizers are allowed only in conventional management based on different regulations of the countries. The European Union is divided into three zones concerning 
the authorisation of a Plant Protection Products and Hungary belongs to the zone "B", with Belgium, Czech Republic, Germany, Ireland, Luxembourg, Netherlands, Austria, Poland, Romania, Slovenia, Slovakia and the United Kingdom. Furthermore in Hungary a list of the currently authorized plant protection products and enhancing substances is published yearly. The dose of applied nitrogen fertilizers is regulated by the Nitrates Directive (1991).

Nowadays, the negative effects of used chemicals on the biodiversity and human health are known (EASAC, 2015; Kim et al., 2017; Kidd et al., 2017), moreover there are several reports on qualitative and quantitative differences of soil microbial community in ecological and conventional managements (Romaniuk et al., 2011; Ge et al., 2013). Beside sustainability, there is growing demand for healthy food and plant production and ecological management opens this door.

The soil microbial community has important role in the soil fertility, because of its influence on the dynamics of organic matter and nutrient cycles (Bowles et al., 2014).

Phospholipid fatty acids (PLFAs) are the main component of the membrane of all living microbial cells, where special PLFA patterns characterise different microbial groups (Gude et al., 2012; Zogg et al., 1997; Zelles et al., 1992; Bossio et al., 1998). Thus, the application of PLFA techniques results in direct information for the grouplevel identification, classification and quantification of microbial community composition (Wu et al., 2009). Properly selected and applied soil cultivation method results in higher soil organic carbon content, hereby provides available nutrients for the soil microbes (Prasad et al., 2016). The microbial activity and biodegradation as well as the organic carbon and total nitrogen content also are more pronounced in the ecological management than in conventional management system (Ge et al., 2013).

The objective of the present study was to give a complex characterization of the studied ecological and conventional sites in a topographically heterogenous area. We hypothesized, that the ecological management had favourable influence on the soil physical and chemical properties as well as on the community structure and microbial activity of soil, hereby contributing to sustainable plant production.

\section{Materials and methods}

\section{Sampling sites and management}

The studied fields belong to the Research Institute of Nyíregyháza, University of Debrecen, in the North-Eastern part of Hungary. The region has a moderately cold-dry continental climate with $10.5{ }^{\circ} \mathrm{C}$ annual mean temperature and 500-750 mm annual mean precipitation. The soil type is acidic sandy soil (Dystric Arenosols) with diverse forms of dunes (Michéli et al., 2006). The selected areas were close to each other (about $400 \mathrm{~m}$, Fig. 1) however, soils varied according to the topographical position (Fig. 2a,b). Soil samples were collected from two representative upper and lower parts of the slope of both ecological and conventional management sites, so we distinguished four sample types: EU: ecological upper part of slope $\left(475849^{\circ} 17^{\prime} \mathrm{N}\right.$ to $475849^{\circ} 72^{\prime} \mathrm{N}$, and $214036^{\circ} 82^{\prime} \mathrm{E}$ to $214037^{\circ} 35^{\prime} \mathrm{E}, 156 \mathrm{~m}$ above the sea level); EL: ecological lower part of slope $\left(475848^{\circ} 81^{\prime} \mathrm{N}\right.$ to $475849^{\circ} 57^{\prime} \mathrm{N}$ and $214031^{\circ} 48^{\prime} \mathrm{E}$ to $214031^{\circ} 97^{\prime} \mathrm{E}, 151 \mathrm{~m}$ above the sea level); CU: conventional upper part of slope $\left(475841^{\circ} 35^{\prime} \mathrm{N}\right.$ to $475841^{\circ} 91^{\prime} \mathrm{N}$ and $214051^{\circ} 10^{\prime} \mathrm{E}$ to $214051^{\circ} 55^{\prime} \mathrm{E}, 158 \mathrm{~m}$ above the sea level); CL: conventional lower part of slope $\left(475842^{\circ} 43^{\prime} \mathrm{N}\right.$ to $475842^{\circ} 99^{\prime} \mathrm{N}$ and $214054^{\circ} 64^{\prime} \mathrm{E}$ to $214054^{\circ} 96^{\prime} \mathrm{E}, 153 \mathrm{~m}$ 
above the sea level). The difference in elevation between the upper and lower part of the slope is $5 \mathrm{~m}$ in both site. We used for the measure of GPS coordinates an Trimble NOMAD $900 \mathrm{G}$ device.

Ecological crop production has been maintained since 1997. In the studied sampling period, cereal crops (rye with hairy vetch and oat) were cultivated in the ecological and conventional fields, respectively. In both managements soils were ploughed upto $30 \mathrm{~cm}$ depth every year. Furthermore, in the conventional management fertilizers and pesticides were applied according to the needs of the plants. In the ecological management the loss of organic and mineral matters were compensated with farmyard and green manure (at least once in 5 years, respectively) and regular incorporation of the crop residues.

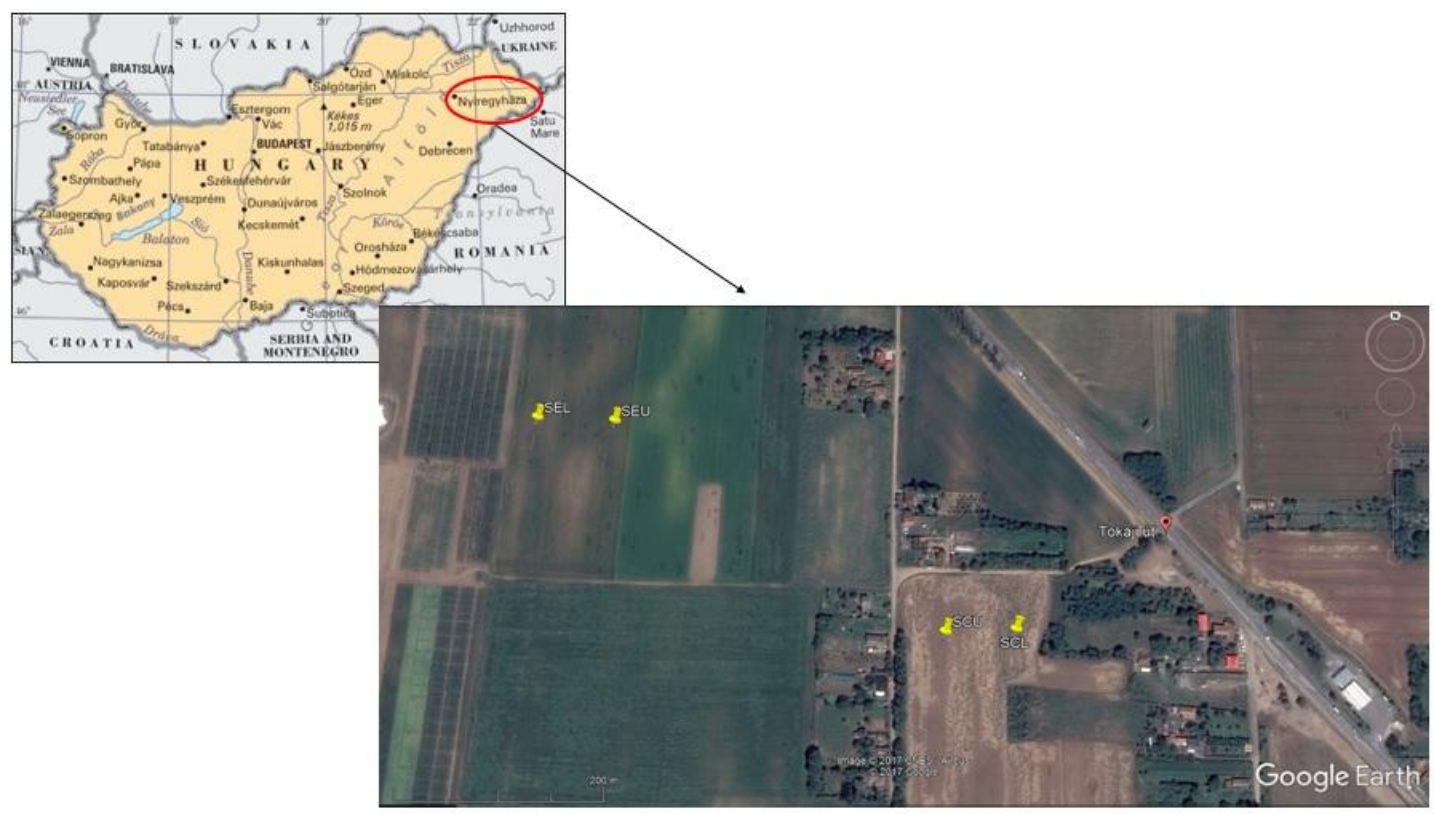

Figure 1. Location of the investigated areas
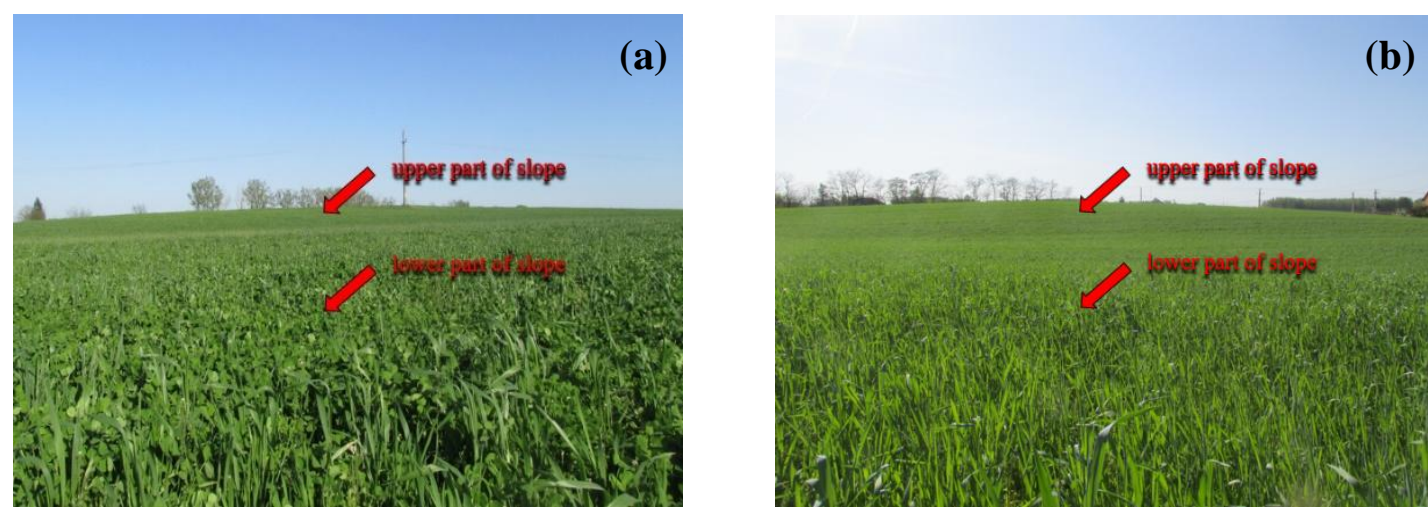

Figure 2. Topographical differencies in ecological (a) and conventional (b) sites

The physical properties indicated the heterogeneity of sandy soils in Nyírség region (Table 1). These parameters were determined with dry sieving and sedimentary method 
from the upper $30 \mathrm{~cm}$ depth interval in autumn 2012 (Buzás, 1993), from the same samples than chemical properties. Although the two investigated sites were located within a few hundred meters, the textures of these soils were different. The soil moisture was significantly higher in the ecological site.

The cultivated plants in ecological field were rye with hairy vetch (the previous crop was buckwheat), and in the conventional site oat was cultivated and rye with hairy vetch was cultivated in 2012 year.

Table 1. Physical soil properties of the investigated soils $(0-30 \mathrm{~cm}, 2012)$

\begin{tabular}{c|c|c|c|c}
\hline \multirow{2}{*}{$\begin{array}{c}\text { Sampling } \\
\text { site }\end{array}$} & gravel & sand & fine sand, silt, clay & soil moisture \\
\cline { 2 - 5 } & \multicolumn{2}{|c|}{$\mathbf{m} / \mathbf{m} \%$ dry matter } & \multicolumn{2}{|c}{$\%$} \\
\hline EU & $30.28 \pm 1.33^{\mathrm{c}}$ & $15.35 \pm 0.52^{\mathrm{a}}$ & $54.37 \pm 1.05^{\mathrm{b}}$ & $5.77 \pm 0.08^{\mathrm{b}}$ \\
$\mathrm{EL}$ & $34.65 \pm 0.54^{\mathrm{d}}$ & $24.07 \pm 0.81^{\mathrm{b}}$ & $41.28 \pm 1.06^{\mathrm{a}}$ & $6.90 \pm 0.29^{\mathrm{c}}$ \\
$\mathrm{CU}$ & $2.53 \pm 0.35^{\mathrm{a}}$ & $15.51 \pm 0.52^{\mathrm{a}}$ & $81.97 \pm 0.69^{\mathrm{d}}$ & $3.17 \pm 0.22^{\mathrm{a}}$ \\
$\mathrm{CL}$ & $9.39 \pm 1.63^{\mathrm{b}}$ & $17.91 \pm 0.95^{\mathrm{a}}$ & $72.71 \pm 2.44^{\mathrm{c}}$ & $2.58 \pm 0.16^{\mathrm{a}}$ \\
\hline
\end{tabular}

${ }^{1}$ Data are expressed as mean \pm standard error $(\mathrm{n}=12)$

${ }^{2}$ Within a column the letters following the numbers represent the differences by one-way ANOVA followed by Tukey's-b test $(\mathrm{P}<0.05)$

${ }^{3} \mathrm{EU}$, ecological upper part of the slope; EL, ecological lower part of the slope; $\mathrm{CU}$, conventional upper part of the slope; CL, conventional lower part of the slope

\section{Sampling time and method}

Samples were collected in two different seasons. The first sampling was completed in autumn 2012 (25-26 October), and the second sampling was done on 25 April 2013. The observed anomalies of weather are shown in Fig. 3, based on the data of the meteorological station of the Research Institute of Nyíregyháza.
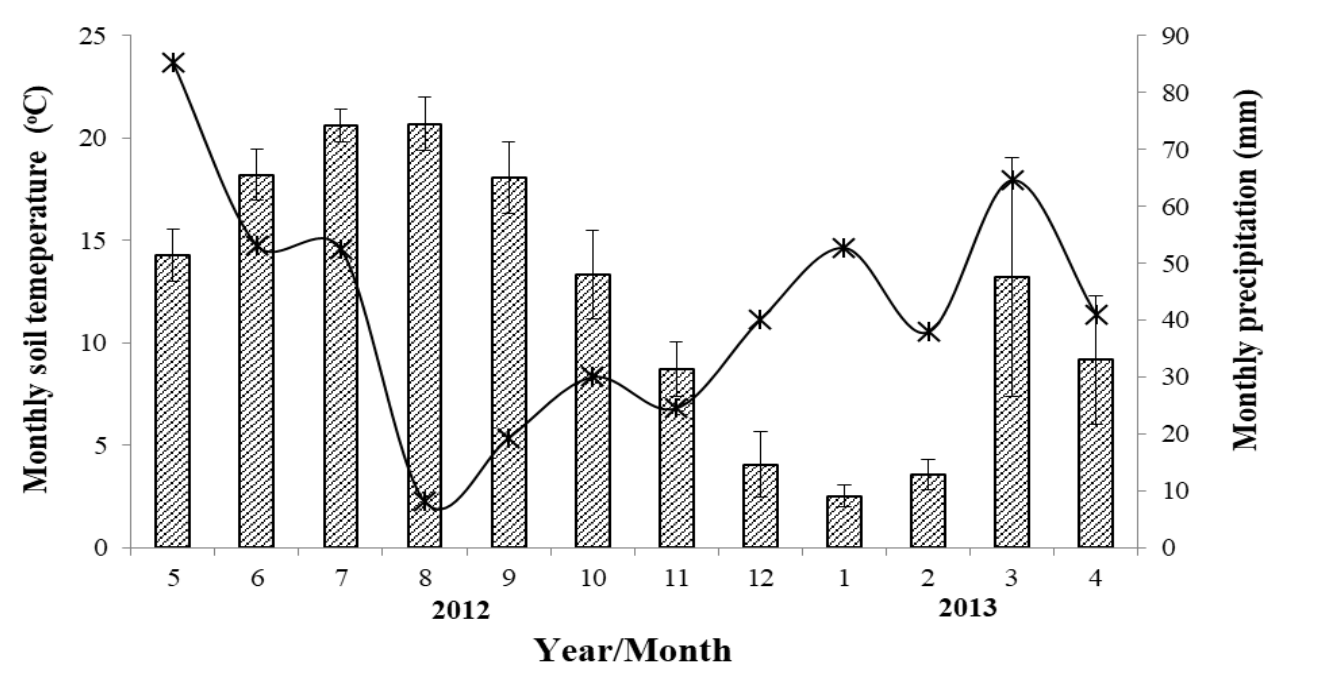

Figure 3. Soil temperature and precipitation of the investigated areas measured by the Research Institute of Nyirregyháza, from May 2012 until April 2013. Data were provided by a $\mu$ Metos meteorological station (Pessl Instruments GmbH., Weiz, Austria), which recorded the data in every 2 minutes in the area of the Research Intstitute 
Soil samples were collected from two depth intervals, 0-30 cm (ploughed) and 30-60 $\mathrm{cm}$, in four repetitions. One repetition is a composite of four drilled subsamples. Samples for microbial analysis were put into a cooler bag in the field, and were frozen immediately after being carried to the laboratory. The samples for chemical analysis were stored air-dried until the analysis.

\section{Determination of chemical soil properties}

These properties were measured in the samples collected from the $0-30 \mathrm{~cm}$ soil depth. The larger plant roots were removed and the air-dried samples were sieved (2 $\mathrm{mm}$ mesh size) before the chemical analyses. Soil $\mathrm{pH}$ was measured with a HachLange, HQ411D type digital pH meter (Hach-Lange, Loveland, Colorado, USA) in a 1:2.5 soil:KCl suspension (MSZ-08-0206-2 Hungarian Standard Method, 1978). Total carbon $(\mathrm{C})$ and nitrogen $(\mathrm{N})$ content were measured with varioMax CNS elemental analyser (Elementar Analysensysteme $\mathrm{GmbH}$, Hanau, Germany). The organic carbon content was measured spectrophotometrically (UNICAM UV2 spectrophotometer, Thermo Scientific, Waltham, Massachusetts, USA) after acidic digestion (potassium dichromate and cc. sulphuric acid; MSZ-08-0452 Hungarian Standard Method, 1980). The $\mathrm{KCl}$ extracted nitrite-nitrate-N concentration was measured with an autoanalyzer FIA Star 5000 (Foss, Hilleroed, Denmark; MSZ 20135 Hungarian Standard Method, 1999).

\section{Phospholipid fatty acid (PLFA) analysis}

For PLFA analysis the samples were chosen based on the results of enzyme activities measurements. PLFAs were extracted, fractionated and methylated as described by White et al. (1979) with minor modifications. Methyl nonadecanoate was used as internal standard after the methylation step. The prepared samples were stored at $-20{ }^{\circ} \mathrm{C}$ until the analysis. The PLFAs were separated and identified using a gas chromatographmass spectrometer system (GC 6890N with MS 5975, Agilent, Santa Clara, CA, USA) with a $100 \mathrm{~m}$ Supelco SP-2560 column, in selected ion mode and scan mode as well (50-350 amu).

Detected PLFAs were expressed in nmol PLFA g ${ }^{-1}$ dry soil unit (the results were corrected with the soil moisture content), and these data were used to represent the different microbial groups of soil. The unbranched, saturated PLFAs 14:0, 15:0, 16:0 and 18:0 represented the general bacterial biomass (Gude et al., 2012). The branched, saturated PLFAs iC15:0, aC15:0, iC16:0, iC17:0, aC17:0 indicated the G-positive $\left(\mathrm{G}^{+}\right)$ (Zogg et al., 1997), as well as the monoenoic and cyclopropane unsaturated C16:1n7c, C16:1n5c, C18:1n9c, cyC19:0 indicated the G-negative $\left(\mathrm{G}^{-}\right)$bacteria (Zelles et al., 1992). The $10 \mathrm{MeC} 16: 0$ and $10 \mathrm{MeC} 17: 0$ represented the Actinobacteria (Bossio et al., 1998), and C18:2n6 was used as a fungi marker (White et al., 1979). Sum of these measured PLFAs were used to calculate the total PLFA concentration of the soil microbial community.

\section{Soil enzyme activities}

Samples were stored at $-20{ }^{\circ} \mathrm{C}$ and were incubated for one day at $4{ }^{\circ} \mathrm{C}$ before the analysis. Before sieving $(\varnothing=2 \mathrm{~mm})$, larger plant roots were removed in the laboratory. Invertase activity was measured photometrically at $508 \mathrm{~nm}$, with 3,5-dinitrosalicylic acid (Mikanová et al., 2001). Catalase activity was determined with potassium 
permanganate titration from air-dried soil samples (MSZ-08-1721/4-86 Hungarian Standard Method, 1986).

\section{Statistical analysis}

All measurements were reported as mean values with standard error (SE). Statistical analysis was done using three internal repetitions respectively $(n=12)$ for the more accurate statistical result except in case of PLFA analyses, where internal repetitions were not measured $(n=4)$. All statistical analyses were carried out with the IBM SPSS Statistics 22.0 software package (IBM Inc., USA), applied a significance level of $\mathrm{P}<$ 0.05 was applied. One-way analysis of variance (ANOVA) followed by Tukey's-b and Games-Howell tests (depending on to results of the test of homogeneity of variences) were used to compare the means of different sampling sites. Correlations between abiotic and biotic soil parameters were determined using Pearson's correlation. Principal Component Analyis (PCA) was used to compare PLFA profiles between two management systems and soil layers. For PCA the two enzyme activities and the PLFA results, furthermore the total $\mathrm{C}$ and $\mathrm{N}$ content were used as variables, because the total $\mathrm{C}, \mathrm{N}$ content significantly influenced these parameters.

\section{Results}

\section{Chemical soil properties}

The soils in the Nyírség region generally have acidic $\mathrm{pH}$ in accordance with the measured low $\mathrm{pH}_{\mathrm{KCl}}(3.89-5.98)$ of the sampling sites (Table 2). The $\mathrm{pH}_{\mathrm{KCl}}$ was more favourable in ecologically managed sites than in conventional sites. Chemical parameters were better on the lower part of slopes, but topography had reverse effect on $\mathrm{pH}_{\mathrm{KCl}}$ because it was higher in the samples originated from the upper part of slopes (EU: 5.98; CU: 3.94) than samples from the lower part of slopes (EL: 5.02; CL: 3.89).

Table 2. The main chemical parameters of investigated soils

\begin{tabular}{c|c|c|c|c|c|c}
\hline $\begin{array}{c}\text { Sampling } \\
\text { site }\end{array}$ & $\mathbf{p H}_{\mathbf{K C l}}$ & total $\mathbf{C}^{*}$ & organic C $^{*}$ & total N & $\mathbf{N O}_{2} \mathbf{N O}_{\mathbf{3}}^{-}-\mathbf{N}^{*}$ & $\mathbf{C}: \mathbf{N}$ ratio \\
\hline $\mathrm{EU}$ & $5.98 \pm 0.13^{\mathrm{c}}$ & $0.573 \pm 0.005^{\mathrm{b}}$ & $0.462 \pm 0.008^{\mathrm{b}}$ & $0.063 \pm 0.000^{\mathrm{b}}$ & $0.012 \pm 0.003^{\mathrm{ab}}$ & $9.13 \pm 0.05^{\mathrm{c}}$ \\
$\mathrm{EL}$ & $5.02 \pm 0.04^{\mathrm{b}}$ & $0.727 \pm 0.033^{\mathrm{d}}$ & $0.711 \pm 0.013^{\mathrm{d}}$ & $0.085 \pm 0.004^{\mathrm{d}}$ & $0.020 \pm 0.001^{\mathrm{b}}$ & $8.52 \pm 0.09^{\mathrm{b}}$ \\
$\mathrm{CU}$ & $3.94 \pm 0.02^{\mathrm{a}}$ & $0.313 \pm 0.003^{\mathrm{a}}$ & $0.236 \pm 0.002^{\mathrm{a}}$ & $0.040 \pm 0.001^{\mathrm{a}}$ & $0.007 \pm 0.000^{\mathrm{a}}$ & $7.91 \pm 0.11^{\mathrm{a}}$ \\
$\mathrm{CL}$ & $3.89 \pm 0.03^{\mathrm{a}}$ & $0.645 \pm 0.016^{\mathrm{c}}$ & $0.556 \pm 0.005^{\mathrm{c}}$ & $0.073 \pm 0.002^{\mathrm{c}}$ & $0.010 \pm 0.000^{\mathrm{a}}$ & $8.88 \pm 0.03^{\mathrm{c}}$ \\
\hline
\end{tabular}

${ }^{*}$ in $\mathrm{m} / \mathrm{m} \%$ dry matter unit

${ }^{1}$ Data are expressed as mean \pm standard error $(n=12)$

${ }^{2}$ Within a column the letters following the numbers represent the differences by one-way ANOVA followed by Games-Howell test $(\mathrm{P}<0.05)$

${ }^{3} \mathrm{EU}$, ecological upper part of the slope; EL, ecological lower part of the slope; CU, conventional upper part of the slope; CL, conventional lower part of the slope

Generally, comparing the two managements, favourable values were found in ecological management, where all the measured chemical parameters were better. The most significant differences were in cases of available- $\mathrm{N}$ and organic- $\mathrm{C}$ content. The values measured in the conventional management on the upper part of slopes are only $58.3 \%$ and $51.1 \%$ of values measured in ecological site, respectively, while on the lower 
part of slopes these portions are $50.0 \%$ and $78.2 \%$, respectively. However the differences in total- $\mathrm{N}$ and total- $\mathrm{C}$ content between the managements were less, $63.5 \%$ and $54.6 \%$ on the upper part of slopes, respectively, while $85.9 \%$ and $88.7 \%$ on the lower part of slopes, respectively. According to the elevation positions, the C:N ratio was higher on the upper part of the slope in ecological site, while in the conventional management higher ratio was measured on the lower part of the slope.

\section{Microbial community structure}

The actual structure of microbial community was identified by PLFA markers. Lower concentrations of the individual PLFA markers were measured in spring 2013 (Table 4) than in the previous sampling time (Table 3). Microbial biomass, estimated as total PLFA showed significant differences $(\mathrm{P}<0.05)$ between the management systems, reliefs and depths. The highest value was measured in EU upper soil depth interval $\left(23.736 \pm 1.05\right.$ nmol PLFA $\left.{ }^{-1}\right)$ in autumn 2012. In the first sampling time the highest $\mathrm{G}^{+}: \mathrm{G}^{-}$ratio was measured in samples from EU 0-30 cm depth interval (1.623 \pm 0.07$)$. Fungi:general bacteria ratio was the highest in $\mathrm{CU}$ in upper soil depth interval $(0.186 \pm 0.01)$. In contrast to the other data, actinobacteria:general bacteria ratio was higher in the 30-60 cm soil depth interval (except in CU), and was significantly higher in ecological fields $(0.291 \pm 0.01$ in EU; $0.162 \pm 0.00$ in EL). There is a large difference in this ratio between the two soil depth intervals in the ecological field while it is similar in both studied depth intervals of conventional field.

Table 3. The PLFAs indicated structure of microbial community in autumn 2012

\begin{tabular}{|c|c|c|c|c|c|c|c|c|}
\hline \multirow{2}{*}{$\begin{array}{l}\text { Biomarker } \\
\text { PLFA }\end{array}$} & \multicolumn{2}{|c|}{$\mathbf{E U}$} & \multicolumn{2}{|c|}{ EL } & \multicolumn{2}{|c|}{$\mathbf{C U}$} & \multicolumn{2}{|c|}{ CL } \\
\hline & $0-30 \mathrm{~cm}$ & $30-60 \mathrm{~cm}$ & $0-30 \mathrm{~cm}$ & $30-60 \mathrm{~cm}$ & $0-30 \mathrm{~cm}$ & $30-60 \mathrm{~cm}$ & $0-30 \mathrm{~cm}$ & $30-60 \mathrm{~cm}$ \\
\hline General bacteria $^{1}$ & $7.998 \pm 0.32^{\mathrm{d}}$ & $1.445 \pm 0.07^{\mathrm{A}}$ & $2.861 \pm 0.13^{\mathrm{b}}$ & $2.193 \pm 0.07^{\mathrm{D}}$ & $3.447 \pm 0.15^{\mathrm{c}}$ & $1.883 \uplus 0.01^{\mathrm{B}}$ & $2.150 \pm 0.05^{\mathrm{a}}$ & $1.048 \pm 0.02^{\mathrm{A}}$ \\
\hline $\mathrm{Gram}^{+}$bacteria $^{1}$ & $8.495 \pm 0.40^{\mathrm{d}}$ & $1.872 \pm 0.09^{\mathrm{A}}$ & $3.347 \pm 0.15^{b}$ & $2.071 \pm 0.06^{\mathrm{C}}$ & $3.685 \pm 0.16^{\mathrm{c}}$ & $1.890 \pm 0.07^{\mathrm{B}}$ & $2.247 \pm 0.06^{\mathrm{a}}$ & $0.766 \pm 0.17^{\mathrm{A}}$ \\
\hline Gram $^{-}$bacteria $^{1}$ & $5.236 \pm 0.22^{\mathrm{d}}$ & $1.169 \pm 0.06^{\mathrm{A}}$ & $2.480 \oplus 0.11^{\mathrm{b}}$ & $1.439 \pm 0.04^{\mathrm{B}}$ & $3.344 \pm 0.14^{\mathrm{c}}$ & $1.452+0.05^{\mathrm{C}}$ & $2.097 \pm 0.05^{\mathrm{a}}$ & $0.583 \pm 0.12^{\mathrm{A}}$ \\
\hline Actinobacteria $^{1}$ & $0.832 \pm 0.06^{\mathrm{d}}$ & $0.421 \pm 0.02^{\mathrm{D}}$ & $0.275 \pm 0.01^{\mathrm{a}}$ & $0.355 \pm 0.01^{\mathrm{C}}$ & $0.430 \oplus 0.02^{\mathrm{c}}$ & $0.201 \pm 0.01^{\mathrm{A}}$ & $0.292 \pm 0.01^{\mathrm{b}}$ & $0.131 \pm 0.00^{\mathrm{A}}$ \\
\hline Fungi $(\mathrm{C} 18: 2 \mathrm{n} 6)^{1}$ & $1.175 \pm 0.04^{\mathrm{d}}$ & $0.134 \pm 0.01^{\mathrm{B}}$ & $0.328 \pm 0.02^{\mathrm{b}}$ & $0.133 \pm 0.00^{\mathrm{A}}$ & $0.641 \pm 0.02^{\mathrm{c}}$ & $0.279 \pm 0.01^{\mathrm{D}}$ & $0.257 \pm 0.01^{\mathrm{a}}$ & $0.115 \pm 0.00^{\mathrm{A}}$ \\
\hline Total PLFA ${ }^{1}$ & $23.736 \pm 1.05^{\mathrm{d}}$ & $5.041 \pm 0.25^{\mathrm{A}}$ & $9.291 \pm 0.39^{b}$ & $6.203 \pm 0.21^{\mathrm{C}}$ & $11.546 \pm 0.51^{\mathrm{c}}$ & $5.691 \pm 0.18^{\mathrm{B}}$ & $7.043 \pm 0.17^{\mathrm{a}}$ & $2.643 \pm 0.05^{\mathrm{A}}$ \\
\hline $\begin{array}{l}\mathrm{Gram}^{+}: \mathrm{Gram}^{-} \\
\text {bacteria }\end{array}$ & 1.62 & 1.60 & $\pm 0.05^{\mathrm{c}}$ & 1.4 & $.04^{\mathrm{b}}$ & $.04^{\mathrm{B}}$ & $\pm 0.02^{\mathrm{a}}$ & $1.313 \pm 0.03^{\mathrm{B}}$ \\
\hline $\begin{array}{c}\text { Fungi:general } \\
\text { bacteria }\end{array}$ & $0.147 \pm 0.01^{\mathrm{c}}$ & $0.093 \pm 0.00^{\mathrm{B}}$ & $0.115 \pm 0.00^{\mathrm{a}}$ & $0.061 \pm 0.00^{\mathrm{A}}$ & $0.186 \pm 0.01^{\mathrm{d}}$ & $0.148 \pm 0.00^{\mathrm{D}}$ & $0.119 \pm 0.00^{b}$ & $0.109 \pm 0.00^{\mathrm{A}}$ \\
\hline $\begin{array}{l}\text { Actinobacteria: } \\
\text { general bacteria }\end{array}$ & $0.104 \pm 0.05^{\mathrm{b}}$ & $0.291 \pm 0.01^{\mathrm{D}}$ & $0.096 \pm 0.00^{\mathrm{a}}$ & $0.162 \pm 0.00^{\mathrm{C}}$ & $0.125 \pm 0.01^{\mathrm{c}}$ & $0.107 \pm 0.00^{\mathrm{A}}$ & $0.136 \pm 0.00^{d}$ & $0.125 \pm 0.00^{\mathrm{D}}$ \\
\hline
\end{tabular}

${ }^{1}$ Data are expressed as mean \pm standard error (nmol PLFA g ${ }^{-1}$ dry soil), $(n=4)$

${ }^{2}$ Within a row the letters following the numbers represent the differences (small letters in 0-30 $\mathrm{cm}$ soil depth and capital letters in 30-60 soil depth) by one-way ANOVA followed by Tukey's$\mathrm{b}$ test $(\mathrm{P}<0.05)$

${ }^{3} \mathrm{EU}$, ecological upper part of the slope; EL, ecological lower part of the slope; CU, conventional upper part of the slope; CL, conventional lower part of the slope

In spring 2013 (Table 4) the $\mathrm{G}^{+}: \mathrm{G}^{-}$bacteria ratio was also higher in the ecological samples on the upper part of the slope $(1.386 \pm 0.05$ in EU), but this ratio was close to each other on the top and the bottom of the hill. Fungi:general bacteria ratio was higher on the upper part of the slope in the upper soil depth interval $(0.160 \pm 0.01$ in EU, $0.223 \pm 0.01$ in CU). In contrast to the other PLFAs, the actinobacteria:general bacteria ratio was higher in the $30-60 \mathrm{~cm}$ depth interval in both managements(except of CL). 
Comparing the managements, significantly higher ratios were found in ecological fields $(0.202 \pm 0.01$ in EU, $0.209 \pm 0.01$ in EL). The calculated ratios show similar trend to the previous sampling time.

Table 4. The PLFAs indicated structure of microbial community in spring 2013

\begin{tabular}{|c|c|c|c|c|c|c|c|c|}
\hline \multirow{2}{*}{$\begin{array}{l}\text { Biomarker } \\
\text { PLFA }\end{array}$} & \multicolumn{2}{|c|}{$\mathbf{E U}$} & \multicolumn{2}{|c|}{ EL } & \multicolumn{2}{|c|}{$\mathbf{C U}$} & \multicolumn{2}{|c|}{ CL } \\
\hline & $0-30 \mathrm{~cm}$ & $30-60 \mathrm{~cm}$ & $0-30 \mathrm{~cm}$ & $30-60 \mathrm{~cm}$ & $0-30 \mathrm{~cm}$ & $30-60 \mathrm{~cm}$ & $0-30 \mathrm{~cm}$ & $30-60 \mathrm{~cm}$ \\
\hline General bacteria $^{1}$ & $3.047 \pm 0.13^{\mathrm{d}}$ & $0.508 \pm 0.01^{\mathrm{A}}$ & $2.218 \pm 0.11^{\mathrm{b}}$ & $0.728 \pm 0.03^{\mathrm{B}}$ & $1.730 \pm 0.29 a$ & $0.895 \pm 0.02^{\mathrm{C}}$ & $2.816 \pm 0.09^{c}$ & $1.018 \pm 0.03^{\mathrm{D}}$ \\
\hline Gram $^{+}$bacteria $^{1}$ & $3.396 \pm 0.14^{c}$ & $0.871 \pm 0.03^{\mathrm{C}}$ & $2.402 \pm 0.11^{\mathrm{b}}$ & $0.603 \uplus 0.03^{\mathrm{B}}$ & $1.822 \pm 0.07^{\mathrm{a}}$ & $0.431 \pm 0.02^{\mathrm{A}}$ & $3.479 \pm 0.12^{\mathrm{d}}$ & $1.310 \pm 0.04^{\mathrm{D}}$ \\
\hline Gram $^{-}$bacteria $^{1}$ & $2.451 \pm 0.10^{c}$ & $0.673 \uplus 0.02^{\mathrm{C}}$ & $1.863 \pm 0.09^{b}$ & $0.467 \pm 0.02^{\mathrm{B}}$ & $1.366 \pm 0.05^{\mathrm{a}}$ & $0.349 \pm 0.01^{\mathrm{A}}$ & $2.747 \pm 0.11^{\mathrm{d}}$ & $0.999+0.04^{\mathrm{D}}$ \\
\hline Actinobac & $0.244 \pm 0.01^{\mathrm{c}}$ & $0.181 \pm 0.01^{\mathrm{C}}$ & $0.178 \pm 0.01^{\mathrm{a}}$ & $0.152 \pm 0.01^{\mathrm{B}}$ & $0.186 \pm 0.01^{\mathrm{b}}$ & $0.075 \pm 0.00^{\mathrm{A}}$ & $0.343 \pm 0.02^{\mathrm{d}}$ & $0.199+0.01^{\mathrm{D}}$ \\
\hline Fungi (C18 & $0.487 \pm 0.02^{\mathrm{d}}$ & $0.060 \pm 0.00^{\mathrm{D}}$ & $0.347 \pm 0.02^{\mathrm{a}}$ & $0.041 \pm 0.00^{\mathrm{A}}$ & $0.385 \pm 0.01^{\mathrm{c}}$ & $0.043 \pm 0.00^{\mathrm{B}}$ & $0.378 \pm 0.01^{\mathrm{b}}$ & $0.059 \pm 0.00^{\mathrm{C}}$ \\
\hline Total I & $9.625 \pm 0.39^{c}$ & $2.679 \pm 0.07^{\mathrm{C}}$ & $7.009 \pm 0.06^{b}$ & $1.993 \uplus 0.08^{\mathrm{B}}$ & $5.489 \pm 0.22^{\mathrm{a}}$ & $1.405 \pm 0.04^{\mathrm{A}}$ & $9.763 \pm 0.41^{\mathrm{d}}$ & $3.585 \pm 0.15^{\mathrm{D}}$ \\
\hline $\begin{array}{l}\operatorname{Gram}^{+}: \mathrm{Gram}^{-} \\
\text {bacteria }\end{array}$ & 1.386 & 1.295 & 2070.01 & $.05^{\mathrm{B}}$ & $0.05^{\mathrm{c}}$ & $0.04^{\mathrm{A}}$ & $1.266 \pm 0.05^{\mathrm{a}}$ & $0.05^{\circ}$ \\
\hline $\begin{array}{c}\text { Fungi:general } \\
\text { bacteria }\end{array}$ & $0.160 \pm 0.01^{\mathrm{c}}$ & $0.067 \pm 0.00^{\mathrm{C}}$ & $0.157 \pm 0.01^{b}$ & $0.057 \pm 0.00^{\mathrm{A}}$ & $0.223 \uplus 0.01^{\mathrm{d}}$ & $0.085 \pm 0.00^{\mathrm{D}}$ & $0.134 \pm 0.01^{\mathrm{a}}$ & $0.058 \pm 0.00^{\mathrm{B}}$ \\
\hline $\begin{array}{l}\text { Actinobacteria: } \\
\text { general bacteria }\end{array}$ & $0.080 \pm 0.00^{\mathrm{a}}$ & $0.202 \pm 0.01^{\mathrm{C}}$ & $0.080 \pm 0.00^{\mathrm{a}}$ & $0.209 \pm 0.01^{\mathrm{D}}$ & $0.107 \pm 0.00^{b}$ & $0.149 \pm 0.00^{\mathrm{A}}$ & $0.122 \pm 0.01^{\mathrm{c}}$ & $0.195 \pm 0.01^{\mathrm{B}}$ \\
\hline
\end{tabular}

${ }^{1}$ Data are expressed as mean \pm standard error (nmol PLFA g ${ }^{-1}$ dry soil), $(\mathrm{n}=4)$

${ }^{2}$ Within a row the letters following the numbers represent the differences (small letters in 0-30 cm soil depth and capital letters in 30-60 soil depth) by one-way ANOVA followed by Tukey's-b test $(\mathrm{P}<0.05)$

${ }^{3} \mathrm{EU}$, ecological upper part of the slope; EL, ecological lower part of the slope; $\mathrm{CU}$, conventional upper part of the slope; CL, conventional lower part of the slope

\section{Soil enzyme activities}

Both measured enzyme activities showed similar trends to the main chemical parameters with higher values in the ecological field and in the upper depth interval. In case of invertase enzyme (Fig. 4a,b), a large decrease in activity was observed in spring 2013 in both sampling sites and depth intervals, with most pronounced changes in the upper $30 \mathrm{~cm}$ of EU site $\left(-13.92 \mathrm{mg}\right.$ glucose $* \mathrm{~g}^{-1}$ dry soil $\left.* 4 \mathrm{~h}^{-1}\right)$. However this decrease was more significant, than in the case of PLFAs. In both managements and depth intervals the intensity of decrease was similar, about hundredth.

The invertase activity was effected in different ways by the elevation position. Generally, higher activity was measured in the upper depth interval on the upper part of slopes, while in the 30-60 cm depth interval higher activity was found on the lower part of slopes. The only exception was in the upper depth interval in autumn under conventional management, where the activity was higher on the lower part of the slope.

On the contrary, a slight increase $\left(0.09-0.83 \mathrm{mg} \mathrm{O}_{2} * \mathrm{~g}^{-1} * \mathrm{~h}^{-1}\right)$ of catalase activity was observed in spring 2013 (Table 5), but the ratios of ecological:conventional sites in different elevation positions were similar to the results of autumn 2012. In most cases, the activity was higher on ecological sites and on the lower part of slopes. Our results suggest the higher stability and independence of catalase enzyme from the environmental factors comparing to the invertase activity. 

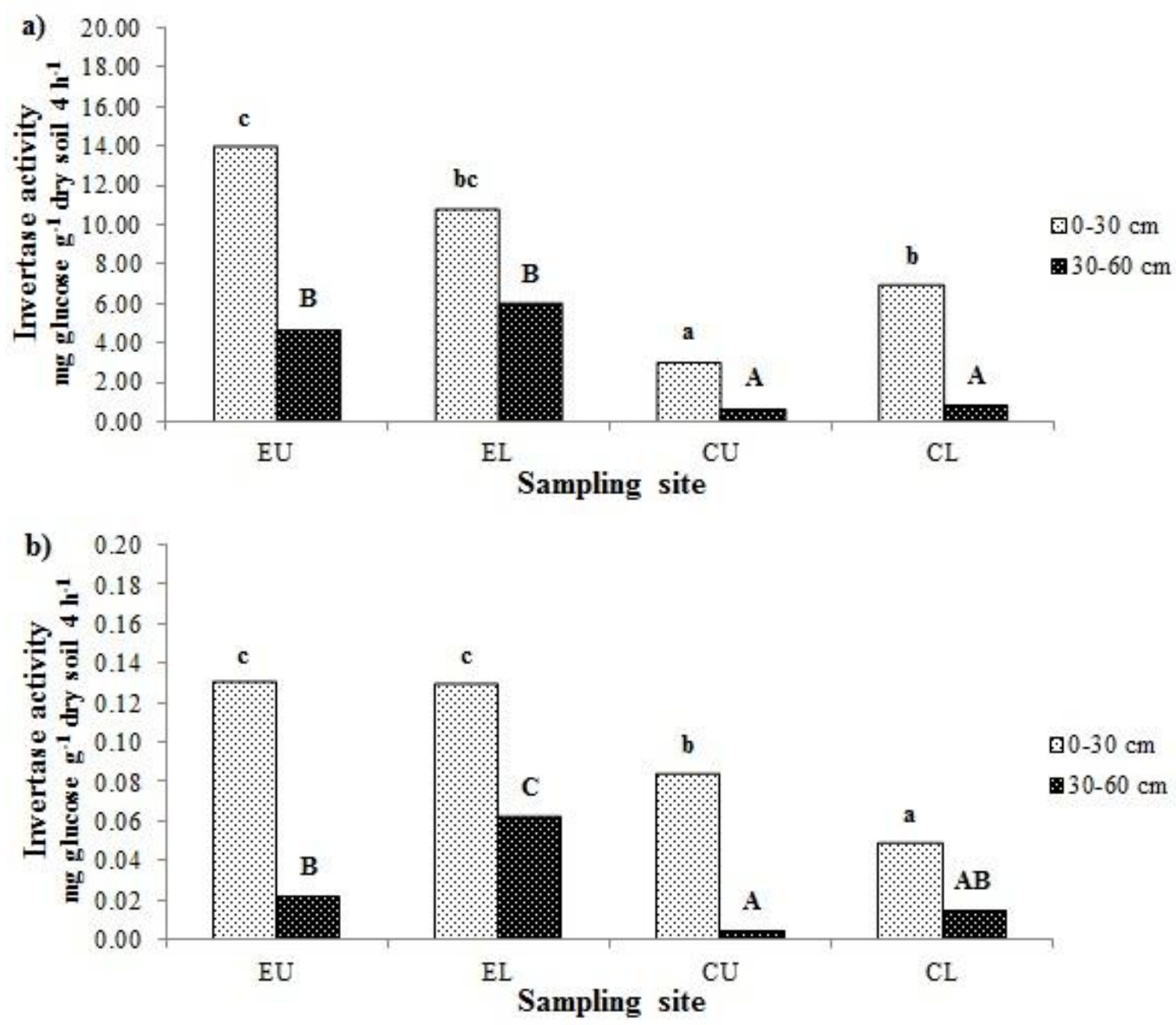

Figure 4. Invertase activity in autumn 2012 (a) and in spring 2013 (b). Above the columns the letters represent the differences (small letters in 0-30 cm soil depth and capital letters in 30-60 soil depth) by one-way ANOVA followed by Games-Howell test ( $n=12 ; P<0.05)$. EU, ecological upper part of the slope; EL, ecological lower part of the slope; $C U$, conventional upper part of the slope; $C L$, conventional lower part of the slope

Table 5. Catalase activity of investigated samples

\begin{tabular}{|c|c|c|c|c|}
\hline \multirow{3}{*}{ Sampling site } & \multicolumn{4}{|c|}{ Catalase activity $\left(\mathrm{mg} \mathrm{O}_{2} \mathrm{~g}^{-1}\right.$ dry soil $\left.\mathrm{h}^{-1}\right)$} \\
\hline & \multicolumn{2}{|c|}{ Autumn 2012} & \multicolumn{2}{|c|}{ Spring 2013} \\
\hline & $0-30 \mathrm{~cm}$ & $30-60 \mathrm{~cm}$ & $0-30 \mathrm{~cm}$ & $30-60 \mathrm{~cm}$ \\
\hline $\mathrm{EU}$ & $1.548 \pm 0.061^{\mathrm{b}}$ & $1.296 \pm 0.084^{\mathrm{B}}$ & $1.927 \pm 0.073^{\mathrm{b}}$ & $1.210 \pm 0.066^{\mathrm{A}}$ \\
\hline EL & $2.231 \pm 0.091^{\mathrm{c}}$ & $1.845 \pm 0.053^{\mathrm{C}}$ & $2.592 \pm 0.146^{\mathrm{c}}$ & $2.208 \pm 0.155^{\mathrm{C}}$ \\
\hline $\mathrm{CU}$ & $0.823 \pm 0.026^{\mathrm{a}}$ & $0.516 \pm 0.023^{\mathrm{A}}$ & $1.388 \pm 0.086^{\mathrm{a}}$ & $1.006 \pm 0.044^{\mathrm{A}}$ \\
\hline $\mathrm{CL}$ & $1.500 \pm 0.044^{\mathrm{b}}$ & $0.793 \pm 0.085^{\mathrm{A}}$ & $2.072 \pm 0.162^{\mathrm{bc}}$ & $1.618 \pm 0.089^{\mathrm{B}}$ \\
\hline
\end{tabular}

${ }^{1}$ Data are expressed as mean \pm standard error

${ }^{2}$ Within a column the letters following the numbers represent the differences (small letters in 0-30 cm soil depth and capital letters in 30-60 soil depth) by one-way ANOVA followed by Games-Howell test $(\mathrm{n}=12 ; \mathrm{P}<0.05)$

${ }^{3} \mathrm{EU}$, ecological upper part of the slope; EL, ecological lower part of the slope; CU, conventional upper part of the slope; CL, conventional lower part of the slope 


\section{Principal component analysis}

Results of principal component analysis (PCA) indicated that the sampling sites under different managements, elevation positions and depth intervals were separated (Figs. 5-6). In autumn 2012 the first component contained the bacterial PLFA groups and total PLFAs while fungal PLFA belonged to this component just in the upper depth interval. The second component represented $\mathrm{C}$ and $\mathrm{N}$ content, invertase and catalase enzymes in every cases while fungi and actinobacteria PLFAs in the below depth interval. Ratios of individual microbial groups usually were weak indicators of soil properties. In spring 2013 similar trend was observed.
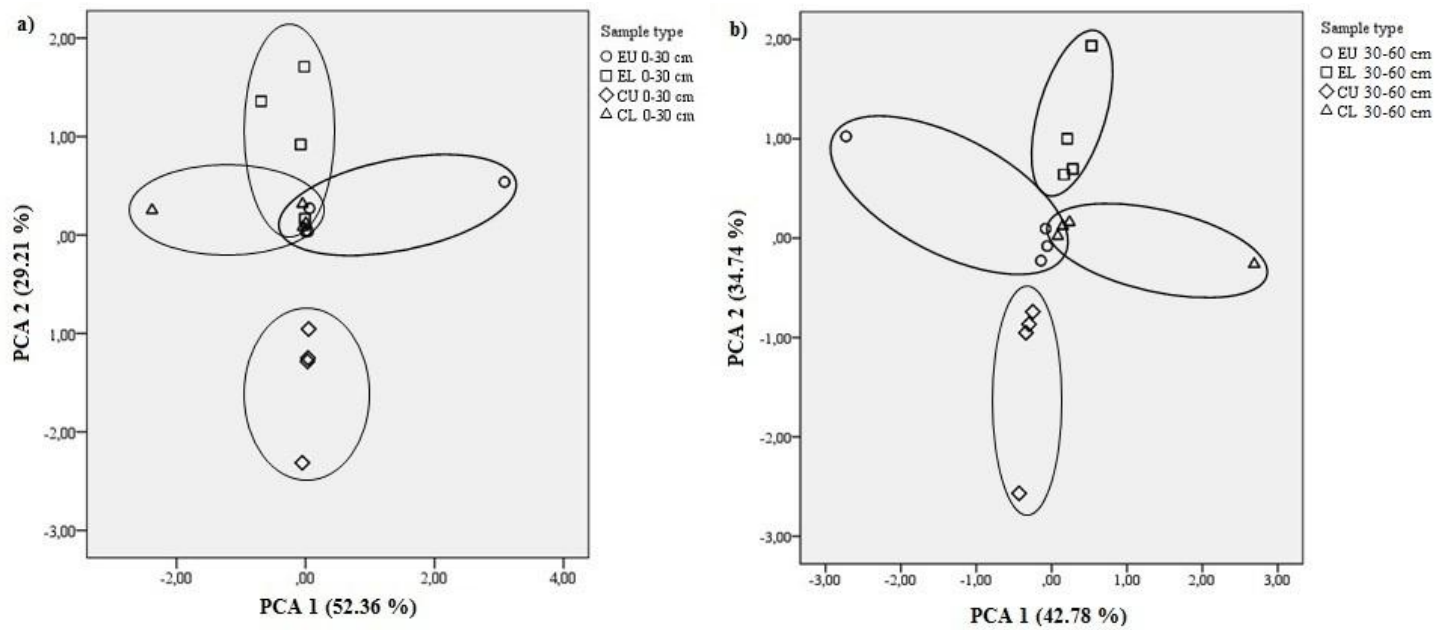

Figure 5. Results of principal component analysis in autumn 2012 from the $0-30 \mathrm{~cm}$ (a) and the $30-60 \mathrm{~cm}$ soil layer (b). EU, ecological upper part of the slope; EL, ecological lower part of the

slope; $C U$, conventional upper part of the slope; $C L$, conventional lower part of the slope
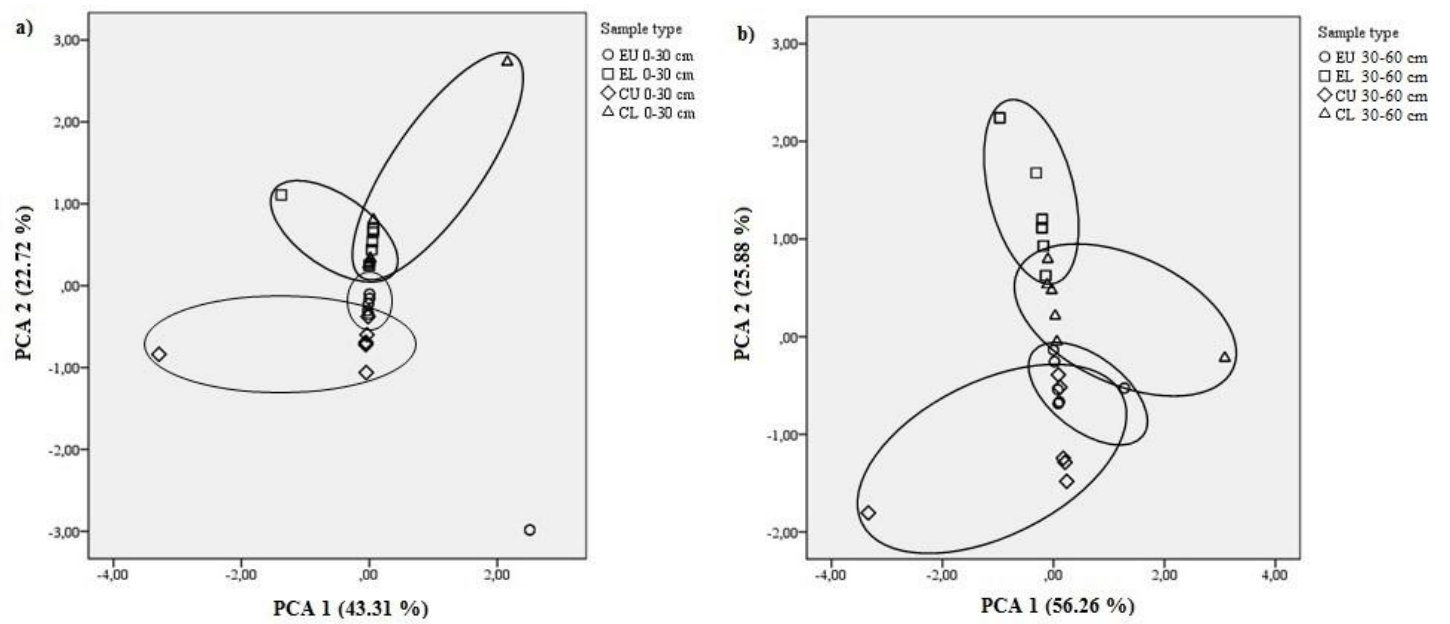

Figure 6. Results of principal component analysis in spring 2013 from the $0-30 \mathrm{~cm}(a)$ and the 30-60 cm soil layer (b). EU, ecological upper part of the slope; EL, ecological lower part of the slope; $C U$, conventional upper part of the slope; $C L$, conventional lower part of the slope 


\section{Discussion}

\section{Chemical soil properties}

Our results excellently presented the heterogeneity of sandy soils in Nyírség region. Earlier results (Yan-Jun et al., 2014; Wang et al., 2013) showed that the nutrient content was more favourable in those sites, where organic manure/crop residues were used as fertiliser, and the higher proportion of larger aggregates $(>2 \mathrm{~mm})$ were observed. This probably resulted in increased microbial biomass and activity with increased extracellular polysaccharides providing good cementing agent to soil aggregation process (Liu, 2007). These are in accordance with our measured enzyme activities and PLFA results. The favourable effect of ecological management is indicated by the smaller difference between the two topographical sites than in conventional field. Furthermore the lower soil moisture in the conventional sites also may be responsible in the lower enzymatic activities (Stark and Firestone, 1995).

The different microorganisms are located in different parts of soil. While bacteria live in the smaller pores, fungi are located in the larger pores and on the surface of aggregates therefore fungi are more sensitive to different environmental effects (Gordon et al., 2008). Nevertheless our sampling sites on hills were not affected by topographical exposure which is proved by the higher microbial activity and PLFA values on the upper part of slopes.

In this study higher soil $\mathrm{pH}$ on ecological site was observed which suggests that organic manure apply and/or lack of fertilizer could, to some extent, alleviate soil acidification. Furthermore, the measured lower values of $\mathrm{pH}_{\mathrm{KCl}}$ in conventional site probable were caused by the acidifying effect of the applied fertilizers (Pais and Horváth, 1990). The $\mathrm{pH}$ seems to be a chemical soil factor with high importance on microbial properties (Bååth and Anderson, 2003; Wang et al., 2013), which is also confirmed the results of our correlation studies (Table 6).

Table 6. Relationships of biotic and abiotic variable pairs in autumn 2012

\begin{tabular}{|c|c|c|c|c|c|c|c|c|c|c|}
\hline Variables & $\mathrm{pH}_{\mathrm{KCl}}$ & Total C & $\begin{array}{c}\text { Organic } \\
\mathbf{C}\end{array}$ & Total N & $\begin{array}{c}\mathrm{NO}_{2}^{-}, \\
\mathrm{NO}_{3}^{-}-\mathrm{N} \\
\end{array}$ & $\begin{array}{l}\text { C:N } \\
\text { ratio } \\
\end{array}$ & gravel & sand & $\begin{array}{l}\begin{array}{c}\text { fine sand, } \\
\text { silt, clay }\end{array} \\
\end{array}$ & $\begin{array}{c}\text { soil } \\
\text { moisture }\end{array}$ \\
\hline Invertase activity & $0.620 * *$ & $0.561 * *$ & $0.495^{* *}$ & $0.504 * *$ & 0.204 & $0.535^{* *}$ & $0.617 * *$ & $0.375^{* *}$ & $-0.621 * *$ & $0.619^{* *}$ \\
\hline Catalase activity & $0.452 * *$ & $0.838^{* *}$ & $0.920^{* * *}$ & $0.843 * *$ & $0.626 * *$ & $0.386^{* *}$ & $0.761 * *$ & $0.738 * *$ & $-0.836^{* *}$ & $0.713^{* *}$ \\
\hline General bacteria & $0.906 * *$ & -0.081 & -0.258 & -0.201 & $0.779 * *$ & 0.458 & 0.390 & -0.188 & -0.277 & 0.444 \\
\hline $\mathrm{Gram}^{+}$bacteria & $0.913 * *$ & -0.079 & -0.243 & -0.182 & $0.778 * *$ & 0.401 & 0.438 & -0.118 & -0.331 & 0.499 \\
\hline Gram $^{-}$bacteria & $0.802 * *$ & -0.291 & -0.423 & -0.358 & $0.612^{*}$ & 0.192 & 0.334 & -0.120 & -0.246 & 0.439 \\
\hline Actinobacteria & $0.843 * *$ & -0.202 & -0.379 & -0.325 & $0.696^{*}$ & 0.421 & 0.275 & -0.282 & -0.162 & 0.343 \\
\hline Fungi (C18:2n6) & $0.798 * *$ & -0.282 & -0.453 & -0.399 & $0.635^{*}$ & 0.369 & 0.215 & -0.313 & -0.106 & 0.296 \\
\hline Total PLFA & $0.884^{* *}$ & -0.141 & -0.305 & -0.244 & $0.738 * *$ & 0.376 & 0.385 & -0.159 & -0.279 & 0.455 \\
\hline $\begin{array}{l}\mathrm{Gram}^{+}: \mathrm{Gram}^{-} \\
\text {bacteria }\end{array}$ & 0.89 & 0.62 & 0.448 & 0.400 & $0.980 * *$ & $0.812 * *$ & $0.654 *$ & 0.039 & -0.544 & 0.565 \\
\hline $\begin{array}{c}\text { Fungi:general } \\
\text { bacteria }\end{array}$ & -0.021 & $-0.949 * * *$ & $-0.971 * *$ & $-0.948 * *$ & -0.276 & -0.344 & -0.468 & -0.464 & 0.487 & -0.297 \\
\hline $\begin{array}{l}\text { Actinobacteria: } \\
\text { general bacteria }\end{array}$ & $-0.733^{* *}$ & -0.561 & -0.554 & $-0.620 *$ & $-0.730^{* *}$ & -0.058 & $-0.990 * *$ & $-0.762 * *$ & $0.980 * *$ & $-0.989 * *$ \\
\hline
\end{tabular}

* Correlation is significant at the 0.05 level (2-tailed)

** Correlation is significant at the 0.01 level (2-tailed)

Among others $\mathrm{pH}$ has strong effect on substrate availability of enzymes (Voroney, 2007) which play the basic role in energy and nutrient supply of microbial communities. Usually the PLFA content increases with increasing pH (Bååth and Anderson, 2003) 
which was proved by the 0.884 correlation coefficient between total PLFA and $\mathrm{pH}_{\mathrm{KCl}}$. That means 2-6 times higher concentrations of different PLFAs in the samples with higher $\mathrm{pH}$.

The organic matter and nutrient pool is more stable where organic nutrient inputs are applied, rather than in case of other nutrient supplying techniques (Nardi et al., 2004). The quality and quantity of plant residues input into the soil can affect the organic matter content of soils (Chen et al., 2000; Edmeades, 2003). Greater than $100 \mathrm{kDa}$ SOM fraction, which improves the soil structure and increases the plant and microbial nutrient uptake, was observed at the highest percentage in case of organic manure application (Dell'Angola et al., 1964). Furthermore, application of animal manure in organic management could increase the microelement content of soil (Bíró et al., 2005). The increasing organic $\mathrm{C}$ and PLFA content of ecological field indicated the possible presence of this SOM fraction. The increase of total and organic carbon, total nitrogen and the carbon:nitrogen ratio in our ecologically managed sampling sites resulted in higher available $\mathrm{N}$ content for plants. Based our results acidic $\mathrm{pH}$ in conventional sites could inhibit the availability of these nutrients.

\section{Soil community structure and microbial activity}

The different organic matter content and the value of available substrates resulted in the structural changes of microbes, because the nutrient supply method had strong effect on the community structure (Hartman et al., 2006). When the easily available, unstable carbon forms are present in the soil, the increase of $\mathrm{G}^{-}$bacteria markers can be observed (Peacock et al., 2001), but less easily available carbon source increases the value of $\mathrm{G}^{+}$ bacteria in the soil (Keynan and Sandler, 1983). The higher $\mathrm{G}^{+}: \mathrm{G}^{-}$bacteria ratio in an ecological site indicates the presence of more stable carbon forms.

Higher rate of fungi in the ecological management than in the conventional one has already observed (Esperschütz et al., 2007; Marschner et al., 2004). The increasing organic matter input resulted in an increase of fungi, thereby the increase of fungi:bacteria ratio (Frostegård and Bååth, 1996). However, our results showed that fungi:general bacteria ratio was depended on the climate conditions and can varied seasonally. In case of easily available fertilizer application the ratio of bacteria increased, because the fungi are primarily responsible for breakdown of the persistent materials (Grayston et al., 2004). This was confirmed by our results, where the values of fungi markers were higher in the ecological samples from the upper $30 \mathrm{~cm}$ soil layer because of the presence of recyclable but not easily available plant residues.

The main difference of the two management systems was found in the upper soil layer. While in this layer the conditions were more favourable for the microbes especially in case of substrates sources (Prasad et al., 2016), the number and activity of microbes were higher and the differences between the two cultivated systems were stronger.

When the values of easily available nutrients decreased, the decomposition process of actinobacteria became dominant (Bastida et al., 2013). The found negative correlation between actinobacteria markers and organic $\mathrm{C}(\mathrm{r}=-0.379)$ indicated that the degradation processes started in autumn after the harvest and recycling of plant residues, but this relationship was not statistically significant.

Seasonal variation had strong effect on the microbial status of soils in both management systems (Fig. 4 and Table 5). In spring 2013 the results were not significantly different probably due to the reduced microbial activity and the inactive 
microorganisms because of the combined effect of autumn soil cultivation and the extremely cold spring weather.

Our study revealed that the land use impact on soil enzyme activities vary under different management and environmental conditions. The recycled plant residues could increase the essential substrates' concentrations of enzymes (e.g. cellulose, hemicellulose) (Wick et al., 1998) which could result in higher enzyme activities. The organic matter, increased by the recycling of plant residues, can protect the extracellular enzymes against destroying them (Martens et al., 1992) and provide their substrates which could increase the enzymes activities in ecological field. However, the acidic pH usually inhibits the microbial activity (Sahoo et al., 2010). Differences are significant also in the lower soil layer which indicate the positive effect of long-term ecological management on the whole soil profile.

Invertase enzyme can break down some carbohydrate polymers at the end of the $\mathrm{C}$ cycle therefore its activity depends on other enzymes using higher organic matter as a substrate. Catalase protected cells against the oxidative damage. Invertase activity usually positively correlated with soil organic carbon and total nitrogen content (Frankenberger and Johanson, 1983). Catalase activity usually was stable in the soil, and showed significant correlation with organic carbon content and reduced with depth (Alef and Nannipieri, 1995). Close vertical connection of different soil layers is represented by the results of invertase activity. The unfavourable climate in spring 2013 decreased the enzyme activity not only in the upper, but also in the lower soil depth interval. Although both measured enzymes are extracellular but their climate-sensitivity seems to be rather different. Similar decreasing of invertase activity and PLFA values suggested the closer connection of invertase activity with the living microbial cells. However, the differences between the PLFA values in two sampling time were not so high than in case of invertase activity. This fact indicated a metabolically inactive microbial biomass (Šnajdr et al., 2008).

Locations of enzymes and PLFAs (living cells) in soil are different: our results suggest that living microbial cells are connected rather to the higher soil particles while enzymes, especially the catalase, are connected rather to the medium sized particles. The soil temperature and moisture, the available substrates are the most dominant factors having combined effects on the seasonal dynamic of microbial activity (BingCheng and Dong-Xia, 2012).

\section{Conclusions}

Beside altered microbial activity, structural changes in microbial biomass were observed between the ecological and conventional managements but the differences were less in unfavourable climate conditions.

We confirmed that as low as $5 \mathrm{~m}$ differences in the topography can result in different physical, chemical and microbiological properties in different soil depth of the upper and lower parts of the slope. These differences due to the elevation positions are less in the ecological field, indicating stronger soil protecting management.

The relationships between living cells and enzyme activities were different at the four studied sites. Our results proved the strong correlation between invertase activity and microorganisms while catalase activity was found more stable and independent from living cell number. The bacterial and fungal microbe groups showed different 
sensitivity to the environmental factors (temperature, moisture, $\mathrm{pH}$ ), and their seasonal variability was also observed.

Ecological management enhanced the microbial activity of acidic sandy soil compared to the conventional one. Positive effects of recycled crop residues were observed in ecological site, but more investigations are required on the relationships between the quality and quantity of recycled crop residues and the different chemical and microbial properties on the upper and lower part of slopes.

Acknowledgements. This work was supported by the Hungarian Research Institute of Organic Agriculture (ÖMKi) and the "GLIA: 2017-1.3.1-VKE-2017-00030" project. We thanks Antal Ferenczy† for his valuable advices in the statistical data evaluation.

\section{REFERENCES}

[1] Alef, K., Nannipieri, P. (1995): Methods in applied soil microbiology and biochemistry. Academic Press, London.

[2] Bååth, E., Anderson, T. H. (2003): Comparison of soil fungal/bacterial ratios in a pH gradient using physiological and PLFA-based techniques. - Soil Biol. Biochem. 35: 955963.

[3] Bastida, F., Torres, I. F., Hernández, T., Bombach, P., Richnow, H. H., García, C. (2013): Can the labile carbon contribute to carbon immobilization in semiarid soils?: Priming effects and microbial community dynamics. - Soil Biol. Biochem. 57: 892-902.

[4] Bing-Cheng, Y., Dong-Xia, Y. (2012): Soil Microbial and Enzymatic Activities Across a Chronosequence of Chinese Pine Plantation Development on the Loess Plateau of China. - Pedosphere 22(1): 1-12.

[5] Bíró, B., Varga, G., Hartl, W., Németh, T. (2005): Soil quality and nitrate percolation as affected by the horticultural and arable field conditions of organic and conventional agriculture. - Acta Agriculturae Scandinavica Section B: Soil and Plant Science 55: 111119.

[6] Bossio, D. A., Scow, K. M., Gunapala, N., Graham, K. J. (1998): Determinants of soil microbial communities: effects of agricultural management, season, and soil type on phospholipid fatty acid profiles. - Microb. Ecology 36: 1-12.

[7] Bowles, T. M., Acosta-Martínez, V., Calderón, F., Jackson, L. E. (2014): Soil enzyme activities, microbial communities, and carbon and nitrogen availability in organic agroecosystems across an intensively-managed agricultural landscape. - Soil Biol. Biochem. 68: 252-262.

[8] Buzás, I. (1993): Soil-and agrochemical methods manual Part. 1. - Inda Publisher, Budapest.

[9] Chen, C., Condron, L. M., Davis, M., Sherlock, R. R. (2000): Effects of afforestation on phosphorus dynamics and biological properties in a New Zealand grassland soil. - Plant Soil 220: 151-163.

[10] Dell'Angola, G., Ferrari, G., Maggioni, A. (1964): Gel filtrazione dell'humus. Nota. Frazionamento della sostanza organica del terreno mediante gel filtrazione con vari tipi di Sephadex. - Ric. Sci. 34: 347-352.

[11] EASAC (European Academies Science Advisory Council) (2015): Ecosystem services, agriculture and neonicotinoids. - EASAC Policy Report 26.

[12] Edmeades, D. C. (2003): The long-term effects of manures and fertilizers on soil productivity and quality: a review. - Nutr. Cycl. Agroecosyst. 66: 165-180.

[13] Esperschütz, J., Gattinger, A., Mäder, P., Schloter, M., Fliessbach, A. (2007): Response of soil microbial biomass and community structures to conventional and organic farming systems under identical crop rotations. - FEMS Microbiology Ecology 61: 26-37. 
[14] Frankenberger, Jr. W. T., Johanson, J. B. (1983): Factors affecting invertase activity in soils. - Plant Soil 74: 313-323.

[15] Frostegård, A., Bååth, E. (1996): The use of phospholipids fatty acid analysis to estimate bacterial and fungal biomass in soil. - Biol. Fertility of Soils 22: 59-65.

[16] Ge, T., Chen, X., Yuan, H., Zhu, B., Li, H., Peng, P., Li, K., Jones, D. L., Wu, J. (2013): Microbial biomass, activity, and community structure in horticultural soils under conventional and organic management strategies. - Eur. J. Soil Biol. 58: 122-128.

[17] Gordon, H., Haygarth, P. M., Bardgett, R. D. (2008): Drying and rewetting effects on soil microbial community composition and nutrient leaching. - Soil Biol. Biochem. 40: 302311.

[18] Grayston, S. J., Campbell, C. D., Bardget, R. D., Mawsdley, J. L., Clegg, C. D., Ritz, K., Griffith, G. S., Rodwell, J. S., Edwards, S. J., Davies, W. J., Elston, D. J., Millard, P. (2004): Assessing shifts in microbial community structure across a range of grasslands of differing management intensity using CLPP, PLFA and community DNA techniques. App. Soil Ecology 25: 63-84.

[19] Gude, A., Kandeler, E., Gleixner, G. (2012): Input related microbial carbon dynamic of soil organic matter in particle size fractions. - Soil Biol. \& Biochem. 47: 209-219.

[20] Hartman, M., Fliessbach, A., Oberholzer, H. R., Widmer, F. (2006): Ranking the magnitude of crop and farming system effects on soil microbial biomass and genetic structure of bacterial communities. - FEMS Microbiology Ecology 57: 378-388.

[21] Keynan, A., Sandler, N. (1983): Spore research in historical perspective. - In: Hurst, A., Gould, G. W. (eds.) The Bacterial Spore Vol. 2. Academic Press, New York 1-48.

[22] Kidd, J., Manning, P., Simkin, J., Peacock, S., Stockdale, E. (2017): Impacts of 120 years of fertilizer addition on a temperate grassland ecosystem. - PLoS ONE 12(3): e0174632. https:// doi.org/10.1371/journal.pone.0174632.

[23] Kim, K. H., Kabir, E., Jahan, S. A. (2017): Exposure to pesticides and the associated human health effects. - Sci. Total Environ. 575: 525-535.

[24] Liu, E. K. (2007): Microbiological features of soil under different fertilization systems and their related soil fertility. PhD Thesis. - Chinese Academy of Agricultural Sciences, Beijing.

[25] Marschner, P., Crowley, D., Yang, C. (2004): Development of specific rhizosphere bacterial communities in relation to plant species, nutrition and soil type. - Plant and Soil 261: 199-208.

[26] Martens, D., Johanson, J., Frankenberger, J. (1992): Production and persistence of soil enzymes with repeated addition of organic residues. - Soil Sci. 153: 53-61.

[27] Michéli, E., Fuchs, M., Hegymegi, P., Stefanovits, P. (2006): Classification of the Major Soils of Hungary and their Correlation with the World Reference Base for Soil Resources (WRB). - Agrokémia és Talajtan (Agrochemistry and Soil Science) 55: 19-28.

[28] Mikanová, O., Kubát, J., Mikhailovskaya, N., Vörös, I., Bíró, B. (2001): Influence of heavy metal pollution on some soil-biological parameters in the alluvium of the Litavka river. - Rostlinná Výroba 47: 117-122.

[29] Nardi, S., Morari, F., Berti, A., Tosoni, M., Giardini, L. (2004): Soil organic matter properties after 40 years of different use of organic and mineral fertilisers. - Europ. J. Agronomy 21: 357-367.

[30] Pais, I., Horváth, L. (1990): Atmospheric Acidic Deposition and Ist Environmental Effect in Hungary. - In: Bresser, A. H. M. and Salomons, W. (eds.) Advances in Environmental Science. - Acidic Precipitation, New-York 193-214.

[31] Peacock, A. D., Macnaughton, S. J., Cantu, J. M., Dale, V. H., White, D. C. (2001): Soil microbial biomass and community composition along an anthropogenic disturbance gradient within a long-leaf pine habitat. - Ecological Indicators 1: 113-121.

[32] Prasad, J. V. N. S., Srinivasa Rao, Ch., Srinivas, K., Naga Jyothi, Ch., Venkateswarlu, B., Ramachandrappa, B. K., Dhanapal, G. N., Ravichandra, K., Mishra, P. K. (2016): Effect of ten years of reduced tillage and recycling of organic matter on crop yields, soil organic 
carbon and its fractions in Alfisols of semi arid tropics of southern India. - Soil Till. Res. 156: 131-139.

[33] Romaniuk, R., Giuffre, L., Costantini, A., Nannipieri, P. (2011): Assessment of soil microbial diversity measurements as indicators of soil functioning in organic and conventional horticulture systems. - Ecol. Indic. 11: 1345-1353.

[34] Sahoo, P. K., Bhattacharyya, P., Tripathya, S., Equeenuddina, S. M., Panigrahia, M. K. (2010): Influence of different forms of acidities on soil microbiological properties and enzyme activities at an acid mine drainage contaminated site. - J. Hazardous Materials 179: 966-975.

[35] Šnajdr, J., Valášková, V., Merhautová, V., Herinková, J., Cajthaml, T., Baldrian, P. (2008): Spatial variability of enzyme activities and microbial biomass in the upper layers of Quercus petraea forest soil. - Soil Biol. Biochem. 40: 2068-2075.

[36] Stark, J. M., Firestone, M. K. (1995): Mechanisms for Soil Moisture Effects on Activity of Nitrifying Bacteria. - Appl. Environ. Microbiol. 61(1): 218-221.

[37] United Nations, Department of Economic and Social Affairs, Population Division (2015): World Population Prospects: The 2015 Revision. - United Nations, New York.

[38] Voroney, R. P. (2007): The Siol Habitat. - In: Paul, E. A. (ed.) Soil Microbiology, Ecology, and Biochemistry. Elsevier, Oxford, p.43.

[39] Wang, F., Tong, Y. A., Zhang, J. S., Gao, P. C., Coffie, J. N. (2013): Effects of various organic materials on soil aggregate stability and soil microbiological properties on the Loess Plateau of China. - Plant Soil Environ. 59: 162-168.

[40] White, D. C., Davis, W. M., Nickels, J. S., King, J. D., Bobbie, R. J. (1979): Determination of the sedimentary microbial biomass by extractible lipid phosphate. Oecologia 40: 51-62.

[41] Wick, B., Khüne, R., Vlek, P. (1998): Soil microbiological parameters as indicators of soil quality under improved fallow management system in South-Western Nigeria. Plant and Soil 202: 97-107.

[42] Wu, Y., Ding, N., Wang, G., Xu, J., Wu, J., Brookes, P. C. (2009): Effects of different soil weights, storage times and extraction methods on soil phospholipid fatty acid analyses. - Geoderma 150: 171-178.

[43] Yan-Jun, C., Xi-Bai, Z., Sheng-Zhe, E., Tao, H., Zong-Xian, C., Shi-Ming, S., Ling-Yu, B. (2014): Response of Soil Organic Carbon and Its Aggregate Fractions to Long-Term Fertilization in Irrigated Desert Soil of China. - J. Integr. Agric. 13: 2758-2767.

[44] Zelles, L., Bai, Q. Y., Beck, T., Beese, F. (1992): Signature fatty acids in phospholipids and lipopolysaccharides as indicators of microbial biomass and community structure in agricultural soils. - Soil Biol. Biochem. 24: 317-323.

[45] Zogg, G. P., Zak, D. R., Ringleberg, D. B., MacDonald, N. W., Pregitzer, K. S., White, D. C. (1997): Compositional and functional shifts in microbial communities due to soil warming. - Soil Sci. Soc. Am. J. 61: 75-481. 